\title{
LEAD TOXICOSIS IN SCAVENGING SPECIES WITHIN THE SOUTHERN GREATER YELLOWSTONE ECOSYSTEM
}

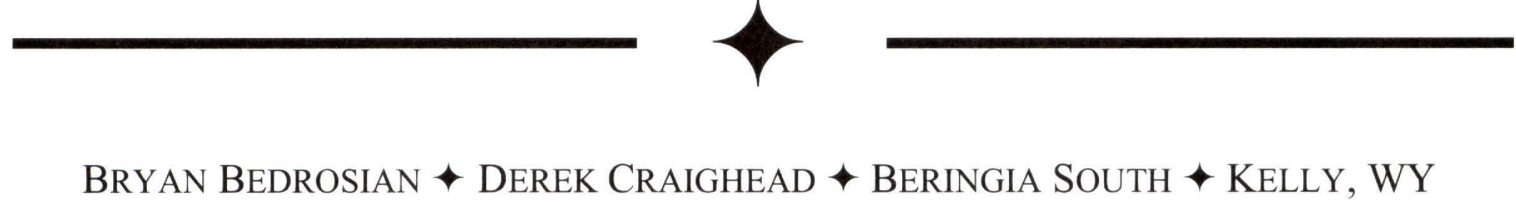

\section{$\uparrow \quad$ INTRODUCTION}

Lead toxicosis in terrestrial birds has been receiving much attention in recent years (for review, see Fisher et al. 2006). Particularly, much of this attention has been focused around the critically endangered California Condors (Gymnogyps californianus) because of the large percentage of free-flying condors that are exhibiting and dying from lead poisoning (Parish et al. 2007). Church et al. (2006) has found that the majority of lead ingested by the condors originates from spent rifle ammunition in offal and big game not retrieved by hunters, thus substantiating the suppositions by Pattee et al. (1990), Miller et al. (1998), and Hunt et al. (2005) that the majority of lead poisoning in condors came from hunting practices. However, condors may not be the only scavenging species at risk from ingesting offal and rifle shot carrion.

There are several studies that describe lead fragmentation of rifle bullets in the carcasses and offal of ground squirrels (Spermophilus richardsonii), prairie dogs (Cynomys ludovicianus), deer (Odocioleus spp.), and elk (Cervus canadensis) and make the argument that these fragments pose a hazard to any potentially scavenging species (Knopper 2005, Pauli et al. 2007, Hunt et al. 2005, and Craighead and Bedrosian 2008). We have recently gathered data to substantiate that claim by finding that Common Ravens (Corvus corax) have significantly higher blood lead levels during the big game hunting seasons in Wyoming than non-hunting periods and nestling controls (Craighead and Bedrosian, 2008).
There have been increasing studies of lead exposure in eagles in recent years also. Kramer and Redig (1997) found that the incidence of lead ingestion in both bald and golden eagles did not change after the ban of lead shot for waterfowl hunting. Further, Miller et al. (1998) and Wayland et al. (2003) both found high incidence of lead poisoning in eagles and found that the times and areas of high exposure were not correlated to waterfowl hunting for both the western US and Great Plains. Both studies suggested that big game hunting may be a significant source of lead exposure for eagles. Conversely, Wayland and Bollinger (1999) found a greater prevalence of lead exposure in bald eagles in areas of high waterfowl hunting in the Canadian prairie provinces, but did not find a similar relationship for golden eagles. Pattee et al. (1990) found that the blood lead levels of golden eagles in California increased from September December and suggested that the increase could have been from deer hunting in the area. All of the studies on lead poisoning and eagles concur that big game hunting could be a cause of lead exposure for those species.

Not only does lead ingestion occur in avian species, but there is a potential for lead ingestion through offal in mammalian species as well. Coyotes (Canis latrans), wolves (C. lupis), cougars (Puma concolor), and fox (Vulpes vulpes) have all been documented to scavenge in the Greater Yellowstone Ecosystem (Wilmers et al. 2003, pers. obs). While coyotes may ingest a larger percentage of offal and un-recovered, hunter shot carcasses than wolves and cougars, 
the potential for lead to occur in the diets of the latter two species still exists.

We investigated the potential correlation between big game hunting and lead exposure in scavengers in the "protected" landscape of Grand Teton National Park, WY, and the southern Greater Yellowstone Ecosystem. We sampled blood lead levels of eagles during and after an annual big game hunt and sampled nestling bald eagles within this area as a control. Further, we tested blood and tissues of cougars, coyotes and wolves to document potential lead ingestion.

\section{$\uparrow \quad$ METHODS}

Eagles were captured within the southern Greater Yellowstone Ecosystem (GYE) $\left(43^{\circ} 91^{\prime} \mathrm{N}, 110^{\circ} 40^{\prime} \mathrm{W}\right)$. The southern GYE is comprised of mainly public land encompassing Grand Teton National Park, the National Elk Refuge and 3 wilderness areas in the surrounding 4 national forests. Elk (Cervus canadesis), deer (Odocioleus spp.), pronghorn antelope (Antilocapra americana) and bison (Bison bison) hunting annually occurs within the valley, and most hunters leave offal from their kills in the field (see Craighead and Bedrosian 2008, for a detailed description of habitat and hunting practices).

Eagles were captured during the winter months of 2005-2006. All but one capture was performed with a net launcher (CODA Ent. Mesa, AZ) using road-killed carrion as bait. The other capture was performed with a modified whoosh net. Eagles were baited with road-killed carrion that was determined not to have been shot. Blood samples from nestlings were taken in cooperation with Grand Teton National Park and Montana State University (A. Harmata) and were sampled from nests within the southern GYE. Once captured, each eagle received a USGS band, was aged, and a $2.0 \mathrm{cc}$ of blood was drawn from the brachial vein for lead analysis and placed in EDTA collection tubes (Becton, Dickinson, and Company, Kranklin Lakes, NJ). Bald eagles were aged based on McCullough (1989), golden eagles were aged based on primary molt patterns (Pyle 2005), and gender was determined for bald and golden eagles by
Bortolotti (1984) and Edwards and Kochert (1986), respectively.

We collected blood samples from the femoral vein of cougars captured during the winter months from 2005-2007. All cougars were live-captured using hounds to tree the individuals and we used rhohimbine to anesthetize the cougar before lowering them from the tree. Cougars received a radio collar, an ear tag, tattoo, and were aged. We obtained tissue samples from two moribund cougars that were later diagnosed with plague. All cougars sampled exhibited home ranges within the southern GYE during sample collection (unpubl. data). Blood samples extracted from coyotes were obtained from Utah State University ( $\mathrm{J}$. Burghardt). Coyotes were live-captured using snare traps, a radio collar was placed on each individual and a blood sample was taken from the femoral vein. We took a liver sample from one road-killed coyote. We obtained blood samples from wolves captured within Grand Teton National Park by the USFWS (M. Jimenez). Liver samples were collected from wolves that had been lethally controlled by the USFWS and AHPIS in the west-central side of the GYE. We took tissue samples as far from the shot trajectory as possible to reduce the potential for contamination from the shotgun shot. Finally, we obtained a liver sample from one road-killed fox.

Most mammalian blood samples were placed in LiHeparin storage tubes (Becton, Dickinson, and Company, Kranklin Lakes, NJ) and tested for BLL using a Leadcare ${ }^{\circledR}$ portable blood lead analyzer (ESA Biosciences Inc., Chelmsford, MA) and recorded in $\mu \mathrm{g} / \mathrm{dL}$. Each Leadcare ${ }^{\circledR}$ sample was tested within $24 \mathrm{~h}$ after collection. Bovine controls were tested periodically to confirm accuracy of the tester and to check for contamination. We also tested wolf blood samples placed in EDTA storage tubes.

Blood samples from eagles and wolves placed in EDTA storage tubes were analyzed for blood lead levels (BLL) by inductively coupled plasma mass spectrometry (ICMPS). These blood samples and all tissues were sent to the Diagnostic Center for Population and Animal Health (Michigan State University, Lansing, MI) 
for ICMPS testing. Each sample was tested for arsenic, cadmium, lead, mercury, selenium and thallium levels. Leadcare ${ }^{\circledR}$ and ICPMS testing are directly comparable using the equation Leadcare $=0.7404($ ICPMS $)-0.4067($ Craighead and Bedrosian2008).

Blood samples from recaptured eagles $(\mathrm{n}=1)$ collected at least two weeks apart were considered independent samples because the lead depuration rate for birds is approximately two weeks (Fry and Maurer 2003, Craighead and Bedrosian 2008). Because of this depuration rate, we did not sample any eagles from 15 December 2006 though 8 January 2007 so we could compare blood lead levels from the hunting and post-hunting seasons. Also, we considered any blood samples taken within the 2 weeks after the end date of the hunting season to be potentially under the influence of the hunt and included them in the "hunt" sample for analysis.

We first tested for differences between blood lead levels of bald and golden eagles using Mann-Whitney because the data were not normally distributed and could not be adequately transformed. We tested for differences in blood lead levels between the hunting and non-hunting season samples using Mann-Whitney and a Kruskall-Wallis test was employed to determine if age was a factor in determining BLLs. Finally, we used chi-square tests to reveal potential differences in the proportion of eagles with clinical lead exposure ( $\geq 60 \mathrm{ug} / \mathrm{dL}$ ) in the hunt versus non-hunt, and to test for differences in the proportion of eagles with sub-clinical exposure $(20 \leq$ BLL $<60)$ and background levels $(<20)$ between the two seasons. We also tested for a correlation between body condition of bald eagles and blood lead levels using a regression analysis. We obtained the body condition index using the residuals of a regression analysis between mass (minus estimated crop weight) and a structural body measurement (bill depth).

\section{$+\quad$ Results}

\section{Eagles}

We captured and tested samples for blood lead levels from a total of 40 eagles, including one recapture $48 \mathrm{~d}$ after initial capture that was considered an independent sample (33 bald eagle and 7 golden eagle samples). From the total sample, we found no difference in the median BLLs between bald and golden eagles ( $\mathrm{P}$ $=0.109, \mathrm{~W}=722.0$; Table 1). However, we did find some evidence to suggest during the hunting season bald eagles exhibited higher BLLs than golden eagles $(\mathrm{P}=0.077, \mathrm{~W}=426.0)$, but sample size for golden eagles was very limited ( $\mathrm{n}$ $=2$ ). There was no difference in BLLs between species during the non-hunting season $(\mathrm{P}=$ $0.315, \mathrm{~W}=30.0)$. We found that age was not a factor in determining BLLs $(\mathrm{P}=0.603, \mathrm{H}=$ 3.64). We therefore decided to pool the data for the subsequent analysis.

We found evidence to suggest that the median BLL during the hunting season was larger than the non-hunt $(\mathrm{P}=0.051$; Figure 1$)$. We found significantly more eagles with acute lead exposure during the hunting season $(\mathrm{P}=$ $\left.0.011, \chi^{2}=6.502\right)$, but there was no difference between season for sub-clinical exposure $(\mathrm{P}=$ $0.736, \chi^{2}=0.113$ ). We found no relationship between body condition index and BLL for bald eagles $(\mathrm{P}=0.75)$. Based on the exposure level criterion defined by Redig (1984), we found $85 \%$ of birds tested had been exposed to lead (Table 2). Further, we found $10 \%$ to have acute lead poisoning and all were sampled during the hunting season. It also appeared that the magnitude of acute poisoning levels increased with the duration of the hunting season (Figure $1)$.

We tested nine cougars for BLLs using the Leadcare ${ }^{\circledR}$ system (Table 3). Median BLL for the combined samples was $1.2 \mu \mathrm{g} / \mathrm{dL}$ (range $=0.6-1.5$; S.D. $=0.26$ ). The median BLL for coyotes was $1.5 \mu \mathrm{g} / \mathrm{dL}(n=4$; range $=0.0-2.0$; S.D. $=1.0$ ). The one wolf tested did not exhibit elevated BLL (Table 3). We tested seven wolf blood samples using ICMPS (5 yearlings and 2 adults). All had BLL $<1.0 \mathrm{ug} / \mathrm{dL}$ (range $=0.4-$ 0.9 ; median $=0.8$; S.D. $=0.21$ ). All liver tissue samples were below detectible limits for lead $(0.5 \mathrm{ppm})$. 


\begin{tabular}{lcccc}
\hline \hline & $n$ & median & SD & range \\
\hline All Captures & & & & \\
All Birds & 40 & 40.9 & 99.4 & $11.6-458.0$ \\
Bald Eagle & 33 & 52 & 107.5 & $11.6-458.0$ \\
Golden Eagle & 7 & 32.7 & 11.7 & $14.1-43.8$ \\
Hunting Season & & & & \\
All Birds & 29 & 55.9 & 113.3 & $14.1-458.0$ \\
Bald Eagle & 27 & 56 & 115.9 & $14.4-458.0$ \\
Golden Eagle & 2 & 19.8 & 8.6 & $14.1-25.5$ \\
Non-Hunting Season & & & & \\
All Birds & 11 & 30.2 & 12.3 & $11.6-53.3$ \\
Bald Eagle & 6 & 27.7 & 13.9 & $11.6-53.3$ \\
Golden Eagle & 5 & 39.3 & 10.3 & $18.1-48.3$ \\
\hline
\end{tabular}

Table 1. Blood lead level $(\mu \mathrm{g} / \mathrm{dL})$ descriptive statistics for Bald Eagles and Golden Eagles captured from November - January in Jackson Hole, Wyoming.

\begin{tabular}{lccc}
\hline \hline Blood lead level & $\mathrm{n}$ & mean & $\mathrm{SD}$ \\
\hline$<20$ & 6 & 15.3 & 2.4 \\
$20-59$ & 22 & 37.3 & 12.3 \\
$60-100$ & 8 & 69.8 & 12.9 \\
$>100$ & 4 & 352.1 & 84.1 \\
\hline
\end{tabular}

Table 2. Mean blood lead levels $(\mu \mathrm{g} / \mathrm{dL})$ of Bald and Golden Eagles captured between November - January in Jackson Hole, Wyoming by exposure levels. Blood lead levels $<20 \mu \mathrm{g} / \mathrm{dL}=$ background, $20-59 \mu \mathrm{g} / \mathrm{dL}=$ exposed, $60-99 \mu \mathrm{g} / \mathrm{dL}=$ clinically affected, and $>100$ $=$ acute lead poisoning (guidelines based on Redig 1984).

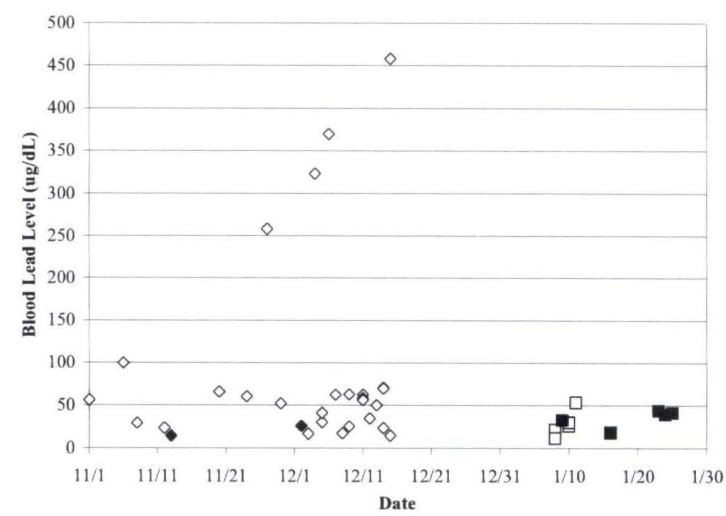

Figure 1. Blood lead levels $(\mu \mathrm{g} / \mathrm{dL})$ of bald eagles (open symbols) and golden eagles (closed symbols) tested during the months of November - January in Jackson Hole Wyoming.

\section{Mammals}

We tested nine cougars for BLLs using the Leadcare ${ }^{\circledR}$ system (Table 3 ). Median BLL for the combined samples was $1.2 \mu \mathrm{g} / \mathrm{dL}$ (range $=0.6-1.5$; S.D. $=0.26)$. The median BLL for coyotes was $1.5 \mu \mathrm{g} / \mathrm{dL}(n=4$; range $=0.0-2.0$; S.D. $=1.0)$. The one wolf tested did not exhibit elevated BLL (Table 3). We tested seven wolf blood samples using ICMPS ( 5 yearlings and 2 adults). All had BLL $<1.0 \mathrm{ug} / \mathrm{dL}$ (range $=0.4$ 0.9 ; median $=0.8$; S.D. $=0.21$ ). All liver tissue samples were below detectible limits for lead (0.5 ppm).

\begin{tabular}{lccc}
\hline \hline Species & $\begin{array}{c}\text { Date } \\
\text { Sampled }\end{array}$ & Age* & $\begin{array}{c}\text { Blood Lead } \\
\text { (ug/dL) }\end{array}$ \\
\hline Cougar & $11 / 5 / 2005$ & 1 & 1.1 \\
Cougar & $1 / 24 / 2005$ & 2 & 1.3 \\
Cougar & $3 / 22 / 2005$ & 3 & 1.5 \\
Cougar & $11 / 13 / 2006$ & 3 & 1.4 \\
Cougar & $11 / 24 / 2006$ & 2 & 0.6 \\
Cougar & $12 / 3 / 2006$ & 2 & 1.2 \\
Cougar & $12 / 11 / 2006$ & 2 & 1.2 \\
Cougar & $2 / 23 / 2007$ & 3 & 1.2 \\
Cougar & $2 / 24 / 2007$ & 3 & 1.0 \\
Coyote & $8 / 17 / 2006$ & 3 & 1.0 \\
Coyote & $8 / 25 / 2006$ & 3 & 0.0 \\
Coyote & $9 / 29 / 2006$ & 3 & 2.0 \\
Coyote & $2 / 18 / 2007$ & 3 & 2.0 \\
Wolf & $6 / 8 / 2006$ & 3 & 0.8 \\
\hline
\end{tabular}

$*$ Kitten $=1$, Sub-adult $=2$, Adult $=3$.

Table 3. Blood lead levels of mammals tested within the southern Greater Yellowstone Ecosystem tested with a Leadcare $\AA$, portable lead tester.

\section{$\downarrow \quad$ DISCUSSION}

We found evidence to support the supposition that eagles are ingesting higher amounts of lead during the hunting season in the southern Yellowstone ecosystem. The clearest sign of increased lead ingestion during the hunt was the proportion of eagles that had both clinical exposure and acute lead poisoning during the hunt ( $20 \%$ and $10 \%$, respectively). No eagle tested exhibited BLLs $>53.3 \mu \mathrm{g} / \mathrm{dL}$ during the non-hunting season (Figure 1). Differences 
between bald and golden eagle BLLs during the hunt is likely an artifact of sample size. We also found no relationship between age and lead exposure, indicating that this phenomenon affects potentially all eagles within this area.

$*$ Kitten $=1$, Sub-adult $=2$, Adult $=3$.

Table 3. Blood lead levels of mammals tested within the southern Greater Yellowstone Ecosystem tested with a Leadcare ${ }^{R}$, portable lead tester.

A large proportion of eagles tested during the non-hunting season had elevated lead levels $(82 \%)$. This is similar to what we observed during the hunting season $(86 \%)$, suggesting that eagles in this area are ingesting lead from a source other than hunter provided carrion. There was a similar proportion of individuals of both bald and golden eagles that exhibited elevated lead levels during the nonhunt ( $83 \%$ and $80 \%$, respectively), suggesting that both species are being exposed from similar sources (e.g., not dietary fish). While the source has yet to be identified, it is likely not carrion, because the ravens within this area exhibit no elevated blood lead levels post-hunt (Craighead and Bedrosian 2008).

We found no evidence to support the supposition that mammals are ingesting unnatural sources or amounts of lead within the GYE. Even after the Leadcare ${ }^{\circledR}$ results had been adjusted to correspond to ICMPS results, the highest BLL we detected was only $2.6 \mathrm{ug} / \mathrm{dL}$, which is well below the elevated BLL threshold. Even though $57 \%$ of the blood samples tested with Leadcare ${ }^{\circledR}$ were collected during the hunting season (Table 3), we found no evidence of acute lead exposure in mammals in the GYE. We also found no evidence to support the notion that mammals in the GYE have had any exposure during their lifetimes. Liver lead levels indicate chronic, lifetime exposure and were all below detectible limits.

A large amount of lead is annually deposited across the nation in the form of very small lead particles in offal and un-retrieved big game (Hunt et al. 2005, Craighead and Bedrosian 2008). A wide variety of scavenging species utilizes this offal for food in the GYE (Wilmers et al. 2003) and, thus, may be vulnerable to lead toxicosis. While our data indicate that lead ingestion may be a serious issue for eagles, mammals may not be at high risk. This difference may be due to different amounts of lead ingested (mammals may utilize food resources other than offal) or differences in lead absorption rates between the classes. Regardless, the amount and severity of the lead ingestion by eagles warrants concern and further investigation.

\section{$\downarrow \quad$ Literature CiTED}

Bortolotti, G.R. 1984. Sexual size dimorphism and age-related size variation in Bald Eagles. Journal of Wildlife Management. 48:72-81.

Church, M.E., R. Gwiazda, R.W. Risebrough, K. Sorenson, C.P. Chamberlain, S. Farry, W. Heinrich, B.A. Rideout, and D.R. Smith. 2006. Ammunition is the principal source of lead accumulated by California Condors re-introduced to the wild. Environmental Science and Technology 40: 6143-6150.

Craighead, D. and B. Bedrosian. 2008. Blood lead levels of common ravens with access to big game offal. Journal of Wildlife Management.72(1):240-245.

Edwards, T. C., Jr. and M.N. Kochert. 1986. Use of body weight and length of footpad as predictors of sex in golden eagles. Journal of Field Ornithology. 57:317319.

Fisher, I.J., D.J. Pain, V.G. Thomas. 2006. A review of lead poisoning from ammunition sources in terrestrial birds. Biological Conservation. V131; 3; P 421-432.

Hunt, W. G., W. Burnham, C. Parish, K. Burnham, B. Mutch, and J.L. Oaks. 2005. Bullet fragments in deer remains: implications for lead exposure in avian scavengers. Wildlife Society Bulletin 33: 167-170.

Fry, D.M. and J.R. Maurer. 2003. Assessment of lead contamination sources exposing 
California Condors. Report of California Department of Fish and Game.

Knopper, L., P. Mineau, A. Scheuhammer, D. Bond, D. McKinnon. 2006. Carcasses of shot Richardson's ground squirrels may pose lead hazards to scavenging hawks. Journal of Wildlife Management 70: 295-299.

Kramer, J.L. and P.T. Redig. 1997. Sixteen years of lead poisoning in eagles, 1980-1995: an epizootiologic view. Journal of Raptor Research 31: 327-332.

McCullough. M.A. 1989. Moulting sequence and aging of bald eagles. Wilson Bulletin. 101:1-10.

Miller. M.J.R., M. Restani, A. R. Harmata, G. R. Bortolotti, and M. E. Wayland. 1998. A comparison of blood lead levels in bald eagles from two regions on the plains of North America. Journal of Wildlife Diseases 34: 704-714.

Parish, C.N., W.R. Heinrich, and W.G. Hunt. 2007. Five years of lead exposure among California condors released in Arizona. Pages In A. Mee, L. S. Hall., and J. Grantham, eds. California Condors in the $21^{\text {st }}$ Century. American Ornithologists' Union and Nuttall Ornithological Club. In press. at www.peregrinefund.org).

Pattee, O.H., S.N. Wienmeyer, B.M. Mulhern, L. Sileo, and J.W. Carpenter. 1981. Experimental lead-shot poisoning in bald eagles. Journal of Wildlife Management 45: 806-810.
Pauli, J.N., and S.W. Buskirk. 2007. Recreational shooting of prairie dogs: a portal for lead entering wildlife food chains. Journal of Wildlife Management 71: 103-108.

Pyle. P. 2005. Remigial molt patterns in North American Falcomiformes as related to age, sex, breeding status, and lifehistory strategies. Condor. 107:823-834.

Redig, P.T. 1984. An investigation into the effects of lead poisoning on Bald Eagles and other raptors: final report. Minnesota Endangered Species Program Study 100A-100B. University of Minnesota, St. Paul.

Wayland, M. and T. Bollinger. 1999. Lead exposure and poisoning in bald eagles and golden eagles in the Canadian prairie provinces. Environmental Pollution 104: 341-350.

Wayland, M., L. K. Wilson, J. E. Elliot, M. J. R. Miller, T. Bollinger, M. McAdie, K. Langelier, J. Keating, and J. M. W. Froese. 2003. Mortality, morbidity, and lead poisoning of eagles in western Canada, 1986-98. Journal of Raptor Research. 37:8-18.

Wilmers, C.C., D.R. Stahler, R.L. Crabtree, D.W. Smith and W.M. Getz. 2003. Resource dispersion and consumer dominance: scavenging at wolf- and hunter-killed carcasses in Greater Yellowstone, USA. Ecology Letters 6: 996-1003. 